\title{
An Engagement with the Theatre Translation of Heiner Mueller's play Verkommenes Ufer Medeamaterial Landschaft Mit Argonauten into Hindi
}

Arati Kumari

\begin{abstract}
This paper looks at the performance of Mueller's play Verkommenes Ufer, through the prism of its Hindi Translation to engage with the pertaining issues related to the field of theatre translation. It is interesting to go about the process of production of his play into Hindi within the context of current debates that are emerging in relation to the translation in the field of theatre. This is particularly relevant as the debates in the field of Theater Translation makes differentiation between the literary translation and the theatre translation on the pretext that a theatre translation is undertaken keeping in mind the hypothetical performance.
\end{abstract}

\section{Introduction}

There is a general view that in the field of the theatre translation there are two key stages in the emergence of the text in the target language and culture; first, as a drama text is created linguistically; and second as the text gets mediated to the larger number of people collectively through the performance and finds its temporary meaning, each time it is performed, in the target culture. Erika Fischer - Lichte, who works primarily in the field of Performance and Aesthetics, also acknowledges these two forms of the existence of a text in the target language and culture: first, as a drama translation for reading and second as a draft for the performance. In her own words, "On the one hand, the drama 
translation - like all the other translations also - acts as a career of the mediation, if they are received in the reading; but on the other hand they can be used as a template/draft for a performance that will in turn act as a real bearer of mediation." ${ }^{\text {A }}$ As a reading text, the drama translation becomes the direct career of the mediation, however according to Fischer - Lichte, as a draft for the performance, it is not a career of the mediation by itself, the mediation happens through the performance. My hypothesis is that Heiner Mueller's "poetic dramaturgy" challenges this view; that the drama translation mediates directly as it is accessed as a reading text and it serves as mere draft for a performance and let the performance act as a real bearer of mediation in the theatre. In Mueller's plays, in fact, the performance makes inroad in the drama text and the performance has to give way to the drama text in the theatre. A reading of the emergence of the play Verkommenes Ufer Medeamaterial Landschaft mit Argonauten ${ }^{2}$ (Water Front Wasteland Medea Material Landscape with Argonauts) into Hindi as a drama text as well as a theatre text could be viewed as an example to show how the drama text refuses to act just as a template when it is used for the performance and how it seeks to find a way for the direct mediation during the performance also.

\section{Discussion:}

This article is divided into three parts:

1 An Engagement with the theoretical debates on the theatre translation

2 Reading the process of the emergence of the Hindi Translation of Heiner Mueller's Verkommenes Ufer $^{3}$

3 Seeing the Hindi Translation as an art in itself 
1. An Engagement with the theoretical debates on the theatre translation: Theatre translation strives to be treated as an independent field and not as a part of field of literary translation; because a text, translated for the theatrical production has different role to play and hence goes through a different kind of process of translation.

It was way back in the 1930s that the semioticians of the Prague School focused on the interrelationship between the written text and the performance, that challenged the old notion of written text being the dominating aspect of the theater as gradually the theatre became more and more performance oriented. This shift in the theatre practice also led some theoreticians of the translation studies to reexamine their theoretical positions towards translating theatre texts.

Susan Bassnett on theatre translation: In the 1980s, Susan Bassnett while engaging herself with the theatre translation drew on the work of the Italian semiotician Marcello Pagnini who advocated the idea of a 'grammar of performance' embedded in the text. According to this position of Bassnett, the translator's job was to decode the gestic text which is concealed in the Source Language (SL) text as undertext and then to translate it into the Target Language (TL), which also has a concealed gestic text. In the second phase Bassnett's position changed drastically. She argued that it is not possible for a translator to draw the 'gestural understructure' from the source text, on the grounds that there cannot be one single 'grammar of performance' embedded in a text when there are as many potential translations of the text as there are different readings. In 1990s in her articles "Translating for the Theatre - Textual Complexities" (1990) and "Translating for the Theatre: The Case 
Against Performability" (1991), she opposed the idea of including the 'extra dimension' in translating for the theatre and focused on the linguistic structure of existing theatre texts. In that case, the task of integrating the written with the other sign systems that constitute the theatrical event is not the translator's but the director's and the playwright's ${ }^{4}$

Whereas Susan Bassnett in the later phase suggested the theatre translators to focus on the linguistic translation of the text on the pretext that it is impossible to find one single 'grammar of performance' embedded in a text and she linked the director and the playwright to the performance aspect of the text; the subsequent debates in the field of translation studies, keep the performance aspect in the centre of the theatre translation process and therefore seeks for a deeper understanding of dramaturgy and a more active participation in the theatre production, by the translator and that makes the translator's artistic input for the performance as valuable as that of the playwright and the director.

Patrice Pavis on the theatre translation: Patrice Pavis saw the theatre translation as more than interlingual translation of the dramatic text. According to him, the purpose of the theatre translation is to pull the Source Text (ST) towards the TL (Target Language) and TC (Target Culture) and it is done in many stages. The text of written translation (T) depends on the initial virtual situation of enunciation T0 and also on the future audience. Both situations are not seen, the first one is related to the ST, the second one is about the situation of enunciation in the target culture. But in the stages that follow, T1 and T2, which are the next situations of enunciation, the translator, as the reader and the dramaturge, uses his skill to translate in the written text, what might have been uttered in the given time and space in the Source Culture and that might be 
uttered in the future situation of enunciation. T3 is stage concretization. The audience receives the text in T3 and T4 stages. Patrice Pavis is of the opinion that the translator knows that the translation cannot preserve the original situation because it is intended for a future situation of enunciation, a situation; the translator may not be familiar with at all. It is only when the translated text is staged for the target audience and culture that the text is surrounded by a situation of enunciation belonging exclusively to the TC. Thus, the translation to various degrees occurs at the intersection of the situations of enunciation. ${ }^{5}$ The confrontation of the situations of enunciation, be it virtual (related to ST) or actual (related to TC), tells Pavis, proposes a performance text, by suggesting the examination of all possible relationships between textual and theatrical signs. ${ }^{6}$ In other words, while translating there is a confrontation of the situations of enunciation and the performance text emerges out of this confrontation, which seeks for the exploration of all possible relationships between the textual and theatrical signs.

On the contrary to Bassnett, Pavis suggests that the theatre translator must take into account the gestic code of the ST, and must engage him/herself in the dramaturgical analysis of the ST while translating the written text. He/she goes through the situations of enunciation (T0, T1, T2, T3, T4) that involves understanding the virtual situation of enunciation, the dramaturgical analysis, a mise en scène, and the delivery of a message to the audience in the process of the translation, although these stages are not aware of each other.

The subsequent debates in the field of Theatre Translation: The discussions that have emerged in recent years show that gradually the theatre translation is paving a different path for itself in the field 
of Translation Studies. As a theatre text is meant to be performed, Andrea Peghinelli in his article, "Theatre Translation as Collaboration: A Case in Point in British Contemporary Drama" (2012) suggests that the theatre translator must be equipped with dramaturgical skills. He argues that since a theater translation has to function within the immediate context of performance - without annotations or editorial commentary, the translator must have a good understanding of the theater as a medium of performance. ${ }^{7}$ Besides, there are untranslatable or unspeakable parts in a drama, that need to be retained in the target language. For this Peghinelli suggests a combination of processes of adaptation, interpretation, paraphrasing, contemporization, and most importantly understanding and collaborating. According to him, the translator, as re-creator of the text, should be acknowledged as a key figure within the collaborative process of production comparable to the role of the playwright, of the dramaturg and of the director." "The re-creation of the text requires a level of dramaturgical skill and creative vision. Alinne Fernandes in her article "Between Words and Silences: Translating for the Stage and the Enlightenment of Paradigms" (2010) suggests to take theatrical sign systems into consideration because, according to her, when one translates for the stage, many questions have to be dealt with arising from the materiality of the theatre. Hence, the translator is required to have the knowledge of and skills for creating a text as a dramatist. ${ }^{9}$ According to Fernandes, translating the performability in a play text means keeping in mind the speakability of the translated play text by the actors. Translating the performability also means shaping language in a way that entices its audience into the here and now of the performance Alinne Fernandes concludes, "The method that informs the development of this stage language necessarily involves the participation of actors and director, which makes it, therefore, co-operative." ${ }^{\prime 10}$ In order to 
translate a text into stage language, Fernandes proposes, the translator can and should actively engage with making theatre as well. Sirkku Aaltonen in her book "Time-sharing on Stage: Drama Translation in Theatre and Society" which got published in 2000, views theatre texts as apartments, spaces to be occupied and manipulated for periods of time by different tenants. According to her, playwrights, translators, stage directors, dress and set designers, sound and light technicians as well as actors, they all contribute to the creation of theatre texts when they move into them and make them their own. ${ }^{11}$ Thus, the theatre translation is a collaborative and ongoing process as each time it is performed it changes itself in different ways.

The theoreticians in the field of theatre translation see theatre translation as a creative activity in itself and the translator as re-creator of the text because the translation is done thinking of the performance. Patrice Pavis argues that the text of the written translation $(\mathrm{T})$ depends on the initial virtual situation of enunciation $\mathrm{T} 0$ and also on the future audience. He proposes different logical stages that the text of the written translation $(\mathrm{T})$ goes through in its emergence, i.e. T0, T1, T2, T3, T4. Other theoreticians contribute also substantially to the translation strategies and the methodologies in the field of theatre translation. As translation for theatre has in view its performance, the collaboration with other agents of theater making, like playwright, director, musician, actors, dramaturge etc come naturally along in the process of the theatre translation. In individual capacity, as Peghinelli suggests, the translator because he/she translates a text for the performance, where there is no scope for any editorial commentary, he/she must use his dramaturgical analysis to come up to a language that conveys best what all a text in the ST has in it 
in terms of the language, culture and the performance, contained in it.

In the light of all the theoretical arguments if we would like to analyse and understand a piece of translation done for the theater performance, we must engage ourselves with its process in the entirety, right from the time of inception of the idea of performing a drama text until its performance.

2. Reading the process of the emergence of the Hindi Translation of Heiner Mueller's Verkommenes Ufer: The theoreticians in the field of theatre translation have emphasized time and again that theater translation is distinct from the literary translation because a theater translation is done for a hypothetical performance. If we view performance to be the key factor in differentiating the theater translation from other translations, also from literary translation, which is predominantly about the linguistic translation, one needs to take into account the debates woven around the concept of the performance and its role in theatre. Erika Fischer - Lichte in her work "Aesthetik des Performativen" "2 says that the theater is today no more dictated by the literary text. According to her, the performance in the theatre happens out of the meeting between the actor and the audience, out of their confrontation, out of their interaction, which emerge out of the directorial strategies for a performance. Similar mechanism is at work, as a theatre translator approaches a drama text for the translation. There is meeting, confrontation, interaction of the two creators (the playwright, the translator), of the two languages (Source and the Target), and of the two cultures (Source and the Target). This section while viewing the playwright (Heiner Müller) and the translator (Ram Gopal Bajaj) as co-creators of the theatre text, performed in Delhi, attempts to understand their distinct view on theatre in relation to 
each other; discusses the process of the emergence of Hindi translation; and analyses the linguistic and the cultural aspects of the Source and the Target texts against the backdrop of the theoretical discussions in the field of theatre translation.

a) The stance of Playwright and the Translator in the world of Theatre: Peter Hacks, Volker Braun and Heiner Müller were three important playwrights after Brecht, in the erstwhile East Germany, whose plays were a critic on the system. Müller was a dramatist, poet, writer, essayist and theatre director. In his work he rejected the linear dramatic narrative and in general he was against the concept of periodization. In a conversation with Eva Brenner he said, "I could write a play similar to Hamletmaschine tomorrow and then the next day write one like Lohndrücker. The notion of periodization is completely nonsense." ${ }^{\prime 3} \mathrm{He}$ intended to write something that $>>$ must be as permanent as possible, regardless of the fact that in East Germany his plays were always produced fifteen years after they were written." ${ }^{\prime 4}$ His writing surpasses the concept of periodization also in the context of this paper as I feel it is vital to engage with the theatre performance of his play Verkommenes Ufer in Hindi an example of the theatre translation, which is creating its own distinct place in the field of translation studies.

Ram Gopal Bajaj, a noted theatre director, academician, actor (in theatre as well as in Films), and translator in India, is well versed in all the areas of theatre including make-up, production design and stage lighting. He has a unique style of presentation and recitation of poetry and is an esteemed elocutionist. His attempts to run the theatre movement devoid of western influences have won him accolades. In his view, "Theatre movement in India has been colonised by multiple forces. Western domination has left a scar on 
the Asian identity of the movement. The artistes are compelled to carry the flag of a particular thinking." 15 Though he has concentrated on working on the plays by Indian playwrights, however, he has not been against a meaningful exchange between the cultures. His interest in bringing a Heiner Mueller's play to Hindi theatre as the director of the National School of Drama, in which he also collaborated as a translator, is to be seen as a meaningful and creative cultural experience, as Nemi Chand Jain sums up, while talking about the new look at the western theatre in the Hindi theatre in India. ${ }^{16}$

If we take into account the view of the playwright, who also happens to be the theatre director and dramaturge, and the view of the translator, who is also a theatre director, actor and dramaturge, we can find some meeting points between the two. Mueller, who does not write his dramas in linear time, and Bajaj's conscious attempt to work with traditional Indian theatre, where time is not seen in linear fashion, brings them together in relation to the concept of 'time'. Another interesting point of meeting between the two of them is their anti-colonial stand, though their anti-colonial views are situated in different contexts. Moreover, Mueller's plays are written in very dense poetic form. Bajaj with his unique style of presentation and recitation of poetry is considered an excellent elocutionist and this poetic understanding makes him equipped to take on Mueller's Verkommenes Ufer for the translation.

The Process of Verkommenes Ufer's Hindi Translation: It is really interesting to talk about the process that the Hindi translation of Verkommenes Ufer went through as it was in the beginning the translation of the translation because Ram Gopal Bajaj had originally translated the play from its English translation into Hindi. In the words of the director, Stephan Suschke, there was ambiguity 
in the English translation, which was, according to Suschke, not adequate translation of Mueller's images in the play. Sometimes the misunderstood formulations were even more cryptic, more unclear. ${ }^{17}$ At this juncture the translator together with the director, who belonged to the language and theatrical and cultural tradition of the $\mathrm{ST}$, became a collaborator in the translation of the text in TL. To go to the core of the Mueller's drama text, an interpreter (Sumit Mahendru) was involved, who knew all three languages English, Hindi and German. Keeping the interpreter in between, Bajaj and Suschke compared the texts word by word, sentence by sentence. This is the closest that the translator could go to the original composition of the text. Thereby the interpreter played a crucial role, who, according to Suschke, worked as the mediator between the cultures, because he knew all the three languages. On a question that I posed to the director, if he views the Hindi Translation as a collaborative work, Stephan Suschke said that between the director and the translator Sumeet Mahendru was important for the work as he knew all the three languages and so he was a mediator between the cultures. To that extent it was a collaboration work, however in the artistic translation of the text, Bajaj had his own share.

This process of the translation makes distinction between mediating the meaning of words, imagery, and the context through the knowledge of source and target language from recreating the ST in another language. The discussion about the text with Suschke, who is a German language speaker as well as an expert in Heiner Mueller's dramaturgy and also the director of the play to be performed in Delhi, is to be seen as a key stage of the translation, that helped Bajaj in pulling the source text towards the target text, as Suschke tells, artistically. This supports the view point of the theoreticians in the field of theatre translation that the translators 
should be seen as re-creator of the play. The re-creation of the text in the source language requires the knowledge and skill for recreating the text as a dramatist. While supporting this view, the following

section reads the Source and the Target texts individually.

\section{c) The Reading of the Source and the Target texts:}

The Source Text: The play begins with a view of the see at Straussburg, which is followed by the astronaut's story, and then there is the description of the modern water front wasteland, then come the women of Kolchis in picture, which merges in the Medea's story in the second part. Medeamaterial is no story of a past; rather it is a very contemporary scene of the present society. He interprets the Medea story in the present context, as he relates Medea to the socioeconomic questions. The third part of the play is a journey through the world with Argonauts and relates us to the memory of the destroyed world. This part of the play has no facts, no society, no system, no history, no world, what it has is landscape, which according to Mueller, resists capitalism.

The play is abstract. A few words, i.e. Bomben, Eastman Colour, No parking, Polyphem present the picture of a technological world. Rom, Nero, Fritz Lang Boris, der Jugoslawische Traum are a few references from the European context. The use of English words in the last part put the play in the global context. Mueller shows that the women's question, the question of guest workers, the question of asylum is the result of the effort of colonizing people in the world and the root of it can be traced back in the mythological stories as well. The play is open in structure; the language is poetic, hence it is open for interpretations. The play has a 'mythic structure' and 'mythical space'. Hence the translator Bajaj encounters a text which 
has references and stories from mythology and history, and it creates a very experimental theatre through its mythical structure and mythical space.

The Target Text: O. F. Babler says in his text in the book The Nature of Translation, "The translator should be enough of a linguist and a literary critic to be able to judge all basic devices and semasiological patterns of the original poem, and it goes without saying that he should be enough of a poet to make a new poem in his own language in place of the original one. To repeat, the translator ought to be a poet as well as an interpreter, and his interpretation ought to be an act of poetry. Or, to put it otherwise, the translation of a poem, in spite of all its firm relations to the original, should constitute a poem in its own right." here, which has a universal theme and which, according to the to the director of the play, Stephan Suschke, required no specific translation, however to retain what the text stands for in terms of content and form, the translator required to be as much of word weaver as the playwright is.

In terms of structure the Hindi translation of Verommenes Ufer follows the original text and retains the montage technique and the three parts of the play text appear as three scenes. At the level of the content also it follows the content of the original one and in the first part it tells the story of the women of Kolchis, second part is the story of the Medea and the third part takes the reader to the world of the Argonauts. The language of the first and third part is sanskritised Hindi, whereas the second part is in Hindustani. The language of the Hindi translation is very poetic. Both the texts (source and target) follow certain rhythm. Certain lines which were highlighted in the ST, are also highlighted in the TT. 
However there are enough references in the Hindi text to reflect on the cultural meeting point of the two texts, as in order to give the essence of the ST, which he envisions in its virtual situation of enunciation (T0) for a future situation of enunciation (T3, T4) as indicated by Patrice Pavis, he tries to find a parallel expression in the TL and TC. We can get a feel of this through few examples:

For example, for "Monatsbinden" the translator uses, "carefree" which is the commonly used sanitary napkin in the target culture and works as a common noun for sanitary napkin. In this sense, it makes it the description of the mass of the people.

"sigri par paka rahi hai bhojan bhat" captures a very local essence of the target language for the source text expression: "Aufplatzt Ihre Weiber stellen das Essen warm"

In the third part, some extra sound is added, like in the second line,

\footnotetext{
"kiski baat hoti hai-

jab meri baat hoti hai - main kaun - $\underline{\text { aai }}$

ye kaun hai?"19

This is translation for:

"Soll ich von mir reden Ich wer

Von wem ist die Rede wenn

Von mir die Rede geht Ich Wer ist das"20

here "aai" (underlined and made bold by me) this sound is not there in the ST.

"MEIN GROSSVATER WAR

IDIOT IN BÖOTIEN"21
} 
All is written in capital letter, but in translation: "mere lakkaddada boatia ke idiot" is not highlighted.

To translate next few lines, some parallel concepts from the TC has been taken. For example,

"Gang durch die Vorstadt Ich Mein Tod"22

"Die Vorstadt" has been translated as Basti, which could mean the settlements for the poor people, as you enter in a big city, just before it. "Mein Tod" has been translated as "Jamdoot" which symbolizes death in Hinduism, so it corresponds to one particular culture of Indian society.

In the ST, "SEEMANNSBRAUT IST DIE SEE"23 is all capital, but in TT "Mallahan ki dulhin hai - sagar" is not highlighted.

In the next lines, the translator gives an alternative for one expression, which stands in the brackets.

"So stand Nero über Rom im Hochgefühl

Bis der Wagen vorfuhr Sand im Getriebe" 24

These lines stand in the TT as following:

"Niro. Aise hi Nero Rom ke upar

rama khada tha mahawinash mein

ki jab tak yaan aaye - nahin rang mein bhang. (lila mein vyaghat nahi) ${ }^{, 25}$

"Ein Wolf stand auf der Straße als er auseinanderbrach" ${ }^{26}$ is translated as following in the TT:

"Gadud dev sa ada raha sadak par

Jab tak sab dhwast hua nahi"' "Gadud dev"28 for wolf again seems to be translator's choice to use an expression which according to him can best relate to an imagery in the ST. 
The couple of examples that I show here, through them I am not trying to analyse the translation of the ST in Hindi, but to support the argument that the translator stands next to the playwright as the re-creator of the text in the TC. As the reading of the TT shows that there are choices made in highlighting the lines, in the choice of the words, even the choice of the language (use of sanskritized Hindi or Urdu or using the English words now and then), using the imagery from the $\mathrm{TC}$, interpreting the lines sometimes etc. There are translation strategies at work here, which can be a further area of investigation; however, here this paper is primarily concerned about seeing the nature and process of the translation in the light of the theoretical arguments taking place in the field of theatre translation.

Translated Text as an art in itself: In drama translation, "the focus is no longer on old linguistic concerns of prescriptive trends of Translation Studies, but on finding creative strategies to produce a translated play text that is a work of art in its own right," explains Alinne Fernandes. ${ }^{29}$ The creative strategies may be born out of the theatre aesthetic, as understanding the mechanisms of the theatre is fundamental for working on the theatre translation, at the same time, a theater translation, as an art, can evoke new ways of doing theatre. As Fernandes says, the translated text does not bring one world into another one in the process of translation; rather it creates a new world in the fusion of the cultural elements. She believes that thereby the materiality of the theatre, where the play will be staged, plays an important role in the recreation of the text in the target language. The materiality of the theatre consists of the space, time, light design, costume, music, and actor and the text, which all make together part of the theatre process of the target culture. These elements together create a performance, which also includes the audience. According to Erika Fischer - Lichte, "The performance 
translates from a foreign language in its own translated drama, from foreign culture in its own culture, so that the performance produces the drama on the stage under the conditions, which the target culture forsees for the theatrical process. These conditions present the frames, which realize themselves out of theatrical as well as social conventions. Within this frame the performance of the translated text works as cultural transformation.",30

It is interesting to note here that when it comes to the theatre production of a translated text, it is not just about translating a text from a foreign language in its own, but also the culture is translated from foreign in its own. There are certain conditions, emerging out of language, culture and theatrical conventions of the target culture, that as Fischer - Lichte mentions, works as a frame, within which the performance of the translation of the text, situated in another linguistic and cultural convention, takes place and hence it has the transformative quality.

The performance of Mueller's Verkommenes Ufer was well thought production which was a translation of not only Mueller's drama text but also of his dramaturgy in the context of the NSD, which has a strong theatre convention of its own. This part takes into account of the NSD's theatre convention, Mueller's dramaturgy, and staging of Verkommenes Ufer against this background.

Theatre Conventions at the NSD: Before we engage ourselves with the performance of Mueller's play into Hindi at the NSD, it is important to have a look at the theatre conventions of the NSD, to take into view the theatre culture, which works as a frame for this performance. 
The NSD Repertory that began functioning as a full fledged performing ensemble in 1975 after the NSD got autonomy from Sangeet Natak Akademi, has impacted decisively the quality and standards of artistic and creative play production all over the country. The Repertory played a crucial role in all areas of theatre, staging spaces, visuals elements, costume, in the use of materials and acting and influenced the theatre practice in other parts of the country. Throughout, it has been a place of experimentation, inventiveness and aesthetic exploration. The language of performance is Hindi, but the Repertory is rich in terms of human resources as it is a place of theatrical exchanges amongst people from diverse cultural and linguistic backgrounds. Nemichandra Jain's remark on the actors coming from diverse cultural background is interesting. He says, "...the theatre cannot become the cultural expression of people without a living relationship with their language which is not merely a superficial or smart use of words or sentences. Besides an awareness of the literary, cultural or social echoes and nuances, it is the rhythm, lilt, tonal structure, pauses, stresses and, of course, proper pronunciation, which together conjure up the magical world of a language with multiple layers of meaning on stage. Since quite a large number of NSD Repertory productions, have been directed by persons who do not know or speak Hindi or any of its dialects well, delving deep into the real resources of the language could not naturally be possible. " ${ }^{31}$ It is interesting to note here that unlike normal theatrical practices, where the theater is seen as a representation of the local language and as a part of the making of the local culture at the same time, because the theater is done in the local language; the NSD Repertory seems to work more as a laboratory for different experimentations as it chooses for its production a language (Hindi) which is not the language of all the actors, directors, and other people involved in the theater making. 
Besides, the actors' training, says Jain, has been, overwhelmingly westernized $^{32}$ and they have been given no exposure to the practices and methods of expression or modes of behavior ${ }^{33}$ in their own performing arts. Hence the Repertory is not the place to give a glimpse on cultural life of one people, speaking one language, rather as I have mentioned above, it is a place for experimentation, it is a laboratory. That leads us to Heiner Mueller's concept on theatre practice, who looks at theater as a laboratory of fantasy.

Heiner Mueller on Theatre: Heiner Müller writes in his autobiography: "This specialization does not interest me, this division of the work, rather the theater as a complete organism". ${ }^{34}$ That is apparent also from the plays that he wrote, which are very experimental in nature and through their content as well as form, they thrive for a complete approach towards them. He looked at theater in totality, and his theater is a synthesis of recitation, liturgy, mask game, dramatic poems, lyric, folksong etc. According to Müller, "Theater will not discover its function as long as it is constituted on the basis of separation of actor and spectator. Theater lives in the tension between stage and audience, from the provocation of texts". ${ }^{35}$ And what will be the function of theater, once the difference between the stage and the spectators is abolished? Müller elaborates, "Then the theater has its very own function: namely that people can play through their own lives, and variations on situations. People who beforehand and afterward do something quite different, then the theater have its own function as a laboratory". ${ }^{36} \mathrm{He}$ imagines the spectators as co-creator in the theatre. According to Müller, for the desired participation of the spectators in theater, the theater must bring some change in its function. And to change the function of the theater, Müller, while writing a theatrical text, does not write a new story. In his plays he uses the already 
given stories to talk about the current issues and he draws some parallel from the common history. One can find some resonance between Müller's idea of theatre and the traditional Indian theater, where, as Nemichandra Jain, states, "The Indian audiences do not need such heavy inducements for participation, they spontaneously discover what they actually share". ${ }^{37}$ This spontaneous discovery of what the actors and the spectators share, can make the spectators cocreators as well. Müller suggests that the actor must not treat the text as a personal property. In a talk with Ruth Berghaus Müller criticizes the actors for such tendencies heavily: "How you describe it, in the case of actors and also in the case of singers, it has to do with the social situation with the actor and the singer. In such cases, they find themselves in a very privileged situation...From there emerges an attitude of private property". ${ }^{38}$ In other words, the spectator's participation in theater is possible, only if the actors don't possess the text. By not possessing it, they can let the spectators have the access to the text.

Stephan Suschke's Performance of the Verkommenes Ufer, Medeamaterial, Landschaft mit Argaunauten: The play was performed in 2001. The stagecraft was done by the director, Stephan Suschke $^{39}$ himself, which didn't change during the entire performance. There were newspapers, all over on the stage, on the floor, on the wall. The stage design showed the domination of the new media over the masses. The costume was also one and the same throughout the performance. The man actors were wearing grey kurta and black pyjamas and were carrying a red towel; the woman actors were wearing green sari with orange border and that is where the play gets locally rooted. There were seven Jasons and seven Medeas in the performance of the play, and two actors were in the role of the sons. The music composer Bhaskar Chandravarkar interprets the play as a rejection of life in the context of Europe. To 
evoke this rejection of life, he used contemporary European music, Manipuri laments, Bengali lullabies and Japenese Cheng music.

The play begins with a piece of music and a song, than the title of the first part of the play, Sahil aur Ujad, is announced. The stage light is blue. There are newspapers everywhere. The actors are hidden under them. One can only see parts of hands and feet. This scene consists of description of a sea beach, a modern city, poverty, modern women, and refers the Argonauts, the women of Kolchis and Medea. The actors describe the scene in a flat tone. The lines, which are given in the text in block letter, and which can be read as a directorial instruction by the playwright, are emphasized during the performance, by repetitively spoken. For example:

Yah vriksh nahi badhega mujhse upar ${ }^{40}$

Sambhog karo aaja pritam pyare ${ }^{41}$

Though the text is read in flat tone, however the director's perspective comes through the laughter, which man actors produce, while delivering these lines:

Aur thal par - samudra tal par -

Medea - bahon me simta uska

Nanha bhai -

Wo gahan visho ki gyata - vidushi $^{42}$

And the woman actors come on the front portion of the stage. One hears a bang, and the next part, Silsila $-e-$ Medea is announced by the actors. The German title is "Medeamaterial", the Hindi title indicates towards the continuation of the story of Medea in the modern world (Silsila - e - Medea) 
The stage design is same. The four woman actors, out of seven, stand in the front, and they are 'Medea', the three, stand behind, and are 'kaniz'. In this scene, there is addition of only one property that is mirrors, which are in different shapes, and hanging to the stage walls. Than the man actors appear on the right side of the stage, and the woman actors on the left side. All the seven women's voices are collective voice of Medea and the men's voices, collective voice of Jason. They confront each other, their voice build a tension on the stage, than the men characters go in the dark area of the stage. There is no exit/entry on the stage. This scene is not presented in traditional dramatic form. There is not one Medea and one Jason on the stage, there is no dialogue as such, there is war of words, delivered in flat tone. The women are wearing red colour on the palm of their hands, which they show very prominently on the stage. The men are wearing red piece of clothes or towels. On one side, this part shows the violence existing in the society, on the other side, it also shows, how men use women for their aggressive violent goals. This part of the play is like a musical text, where the words, the way, they are uttered in a sentence, have a rhythm. The sentences have ups and downs like a musical piece. This scene depicts all the emotions of an individual: love, hatred, revenge, fear, guilt, innocence, helplessness etc in the form of a musical piece in its utterance.

The last part is written in the first person. This part is, however, no objective description of the world, as is done in the first part, rather, as David Barnett states, in this part: "the lyrics 'I' takes over from the impersonal first section. The 'I' creates both a link between the describer and the described as well as giving the scene more cohesion than the collage effects found in the first scene. The category of time is reintroduced and the monologue assumes a more narrative, consecutive tone". ${ }^{43}$ This part is a journey through a 
modern landscape. From a society the audience makes an exit and enters in a landscape. The 'I' travels through the landscape. He goes in the suburb and then in the city. At the end of this part, the 'I' sees the theater of his/her own death. The seaman's adventure ends with the theater of death in the modern time. The stage remains unchanged. The women are sitting quietly; their head is covered with their saris. The men are hiding under the newspapers, as in the first scene. They get up one after another, read one part of the text and die, all in different tones, different ways and different positions. All the man actors in the play are narrators, they are dead, they come out of death, read the lines and are dead again, while the woman actors are sitting silently and are witnessing the destruction.

In Müller's theater, according to Bernhard Greiner, important is: "Vorgang (events on stage), not the doubling of Beschreibung (the text). The two should remain discrete yet simultaneously on stage". ${ }^{44}$ In Suschke's production of the Verkommenes Ufer also, the stage enactment and the text exist side by side. The idea of the co-existance of the text and the performance emerges out of a situation where neither the text tries to codify the performance, nor do the actors try to possess the text. In a talk with Ruth Berghaus Müller criticizes the actors for such tendencies heavily: "How you describe it, in the case of actors and also in the case of singers, it has to do with the social situation with the actor and the singer. In such cases, they find themselves in a very privileged situation, are the product of social compulsions. From there emerges an attitude of private property." 45 Bajaj's translation of Mueller's drama text refuses to be possessed by the actors in Suschke's production. Moreover, the brochure of the play has comments and opinions of all the people involved in the production of the play, along with the Hindi translation of the play, that way, the 
audience has an easy access to the written, spoken, and performed texts of the play. In this sense, the NSD production of Mueller's play is about all three: readability, speakability and performability.

\section{Conclusion:}

Stephan Suschke, the director of the NSD production of the play, read Verkommenes Ufer as a universal text. The text uses the linguistic expressions that describe the modern, industrialized society and can work as a medium to talk about the poverty caused through the mindless process of modernization just anywhere and everywhere in the world. The use of mythological story of Medea in the play is also to be seen as a strategy to make the play more universal and not local, because, Mueller, who has used mythology heavily in his work, defines myth as an international language, thus with the incorporation of mythology, he aims to give a broader connotation to his texts. If viewed in this light, the theatre translation of the Verkommenes Ufer can be seen as an occasion to engage with the poverty, women question and the negative aspect of the modernization, and many other problems of the today's society. The NSD performance, that uses Bajaj's translation of Mueller's text word to word, does not project the German reality through the play, but the Indian reality. In other words, one can say that what differentiates the German reality from Indian one is just the language that is used (Hindi) and the costume that is worn (sari and salwar kurta) or else it is same reality, which Mueller has processed in his text. The word to word delivery of the text in flat tone during the performance presents both the performance text and the linguistic text before the audience. The linguistic text has its own body and the performance text has its own structure, which incorporates the text, light, music, actor, set, costume, and the audience. In that sense, particularly the kind of dramaturgy that Mueller's work demands, 
the translation for his drama texts asks for an engagement with the drama text in a manner that is a strong linguistic as well as a performative engagement with the text and even while the text goes through the performance, it stands out, it exists in the language besides creating a space to do performance around the issues that has provoked the playwright to write a play.

\section{Notes :}

1. Fischer - Lichte, Erika: Die Inszenierung der Übersetzung als kulturelle Transformation, in: Fischer - Liche, Erika, Paul, Fritz, Schultze, Brigitte and Turk, Horst (ed.): Soziale und theatralische Konvention als Problem der Dramenübersetzung, Gunter Narr Verlag, Tübingen. p. 129- 144.

The original Quote: "Einerseits kann die Dramenübersetzung wie alle anderen Übersetzungen auch - als Träger der Vermittlung fungieren, wenn sie in der Lektüre rezipiert wird; andererseits aber läßt sie sich als Vorlage für eine Inszenierung verwenden, die dann ihrerseits als eigentlicher Träger der Vermittlung fungieren wird.” (p. 129) (Translation mine)

2. Mueller, Heiner.2006. Verkommenes Ufer Medeamaterial Landschaft mit Argonauten, Henschel Schauspiel Theaterverlag Berlin GmbH.

3. Verkommenes Ufer I am using to refer to the play "Verkommenes Ufer Medeamaterial Landschaft mit Argonauten" throughout this paper.

4. Ghani, Dr. Hana Khalief: The Translator as Dramatist: On the Problems of Translating Dramatic Text, http://iasj.net/iasj?func=fulltext\&aId=10783.

5. Pavis, Patrice: Problem of Translation for the Stage: interculturalism and modern theatre, (trs. by Loren Kruger), in: "The Play Out of Context: Transferring Plays From Culture to Culture, p. 25-35.

6. Ibid. p. 25-35. 
7. P Peghinelli, Andrea: 'Theatre Translation as Collaboration : A Case in Point in British Contemporary Drama", in: Journal for Communication and Culture 2, no. 1 (Spring 2012) : 20-30, (C) Institute for Communication and Culture, E - ISSN \& ISSN - L : 2247 - 4404. www.jcc.icc.org.ro, p.23.

8. Ibid. p. $23-24$

9. Fernandes, Alinne Balduìno P. 2010. Between Words and Silences : Translating for the Stage and the Enlargement of Paradigms, Scientia Traductionis, $\mathrm{n} 7$.

10. https://periodicos.ufsc.br/index.php/scientia/article/viewFile/1980$\underline{4237.2010 \mathrm{n} 7 \mathrm{p} 119 / 13470 .}$.

11. Ibid. p. 131.

12. Aaltonen, Sirkku. 2000. Time-sharing on stage. Drama Translation in Theatre and Society. Topics in Translation, Multilingual Matters Ltd.

13. The book is published in English with the title, The Transformative Power of Performance - A New Aesthetics, by Erika Fischer-Lichte (Author), Saskya Iris Jain (Translator), Published by Routledge, 2008.

14. Lotringer/Sylvere (ed.), Schütze/Bernhard \& Catherine (Translator): HEINER MÜLLER. Germania. Semiotext (e), Foreign Agent Series, 1990, p, 235.

15. Ibid. p. 212.

16. Thomas, Jerry: Doyen of Hindi Theatre, in "The Hindu", Dec 19, 2002.

http://www.thehindu.com/thehindu/mp/2002/12/19/stories/200212 $\underline{1901060200 . \mathrm{htm}}$

17. Jain, Nemichandra: ASIDES, Themes in Contemporary Indian Theatre, National School of Drama, 2003, p. ix.

18. From an email interview conducted by me with Stephan Suschke.

19. Babler, O. F.: Poe's "Raven" and the Translation of Poetry, in: "The Nature of Translation" (ed. by James S Holmes), Publishing House of the Slovak Academy of Sciences, Bratislava, p. 192-200. 
20. The brochure, Verkommenes Ufer, Medeamaterial, Landschaft mit Argonauten, NSD, New Delhi, 2001.

21. Müller, Heiner: Verkommenes Ufer, Medeamaterial, Landschaft mit Argonauten, Henschel Schauspiel Theater Verlag, Berlin $\mathrm{GmbH}, 2006$.

22. Müller, Heiner: Verkommenes Ufer, Medeamaterial, Landschaft mit Argonauten, Henschel Schauspiel Theater Verlag, Berlin GmbH, 2006.

23. Müller, Heiner: Verkommenes Ufer, Medeamaterial, Landschaft mit Argonauten, Henschel Schauspiel Theater Verlag, Berlin GmbH, 2006.

24. Müller, Heiner: Verkommenes Ufer, Medeamaterial, Landschaft mit Argonauten, Henschel Schauspiel Theater Verlag, Berlin $\mathrm{GmbH}, 2006$.

25. Müller, Heiner: Verkommenes Ufer, Medeamaterial, Landschaft mit Argonauten, Henschel Schauspiel Theater Verlag, Berlin GmbH, 2006.

26. The brochure, Verkommenes Ufer, Medeamaterial, Landschaft mit Argonauten, NSD, New Delhi, 2001.

27. Müller, Heiner:Verkommenes Ufer, Medeamaterial, Landschaft mit Argonauten, Henschel Schauspiel Theater Verlag, Berlin GmbH, 2006.

28. The brochure, Verkommenes Ufer, Medeamaterial, Landschaft mit Argonauten, NSD, New Delhi, 2001.

29. It is a culturally loaded word in the TT.

30. Ibid. p. 125.

31. Fischer - Lichte, Erika: Die Inszenierung der Übersetzung als kulturelle Transformation, in: Fischer - Liche, Erika, Paul, Fritz, Schultze, Brigitte and Turk, Horst (ed.): Soziale und theatralische Konvention als Problem der Dramenübersetzung, Gunter Narr Verlag, Tübingen. p. 129- 144.

32. The original Quote: "Die Inszenierung "übersetzt" daher das aus einer fremden Sprache in die eigene übersetzte Drama aus einer 
fremden (der Ausgangskultur) in die eigene Kultur, indem sie es auf der Bühne unter den Bedingungen produziert, welche ihre Kultur (die Zielkultur) für theatralische Prozesse vorsieht. Diese Bedingungen realisieren sich als eine bestimmte Menge einerseits von theatralischen, andererseits von sozialen Konventionen, die in ihrer Gesamtheit den Rahmen darstellen, innerhalb dessen die Inszenierung der Übersetzung als Prozeß einer kulturellen Tranformation vollzogen wird." (translation mine)

33. Jain, Nemichandra: ASIDES, Themes in Contemporary Indian Theatre, National School of Drama, 2003, p. 35.

34. Ibid. p. 35 .

35. Ibid. p. 35 .

36. Müller, Heiner: Krieg ohne Schlacht, Kiepenheuer \& Witsch, 1992, p. 98. "Mich interessierte natürlich nicht diese Spezialisierung, diese Arbeitsteilung, sondern das Theater als ganzer Organismus." (Translation mine)

37. Lotringer/Sylvere (Hg.), Schütze/Bernhard \& Catherine (Übersetzer): HEINER MÜLLER. Germania. Semiotext (e), Foreign Agent Series, 1990, S, 138.

38. Calandra/Devis: New German Theater, Macmillan Press Ltd., London and Basingstoke, 1983, S. 121.

39. Jain/Nemichandra: ASIDES, National School of Drama, New Delhi, 2003, S. 70.

40. Neef/Sigfired: Ruth Berghaus und Heiner Müller im Gespräch. In: "Sinn und Form", 41. Jahr, 1989, 1. Heft, S. 114-131. (My own translation)

41. In the late eighties and in nineties Suschke was a close associate of Heiner Mueller in the productions at the German Theater, Berlin. He played an important role during the production of Der Lohndruecker, Hamletmaschine, Der aufhaaltsame Aufstieg des Arturo Ui" and was the assistant director during the production of Tristone und Isolde, which Mueller directed for the Bayreuth Festival in 1993. In the year 2003, he wrote the book, "Mueller macht Theater", in which he talks about his experience of working together with Heiner Mueller. He chose Medeamaterial for the 
NSD Production with the students because according to him it is a universal text and it could be related to the role of women in Indian society and with the poverty that is described in the first part of the play. Besides it also offered the possibility for very different experiences with a European play, the possibility of chores, and also individual acting experiences. http://www.stephansuschke.de/texte/Fragen Suschke 1.pdf (the interview was conducted in German Language)

42. The brochure, Verkommenes Ufer, Medeamaterial, Landschaft mit Argonauten, NSD, New Delhi, 2001.

43. Barnett/David: Literature versus Theater, Peter Lang, Bern, Berlin, Frankfurt/Main, New York, Paris, Wien, 1998, S. 223.

44. Ibid. S. 21.

45. Neef/Sigfired: "Ruth Berghaus und Heiner Müller im Gespräch". In: Sinn und Form, 41. Jahr, 1989, 1. Heft, S. 114-131.(My own translation)

\section{REFERENCES}

Aaltonen, Sirkku.2000. Time-sharing on stage. Drama Translation in Theatre and Society. Topics in Translation, Multilingual Matters Ltd.

Babler, O. F.1970. Poe's "Raven” and the Translation of Poetry, in: "The Nature of Translation" (ed. by James S Holmes), Publishing House of the Slovak Academy of Sciences, Bratislava, pp. 192-200.

Barnett, David. 1998. Literature versus Theater, Peter Lang, Bern, Berlin, Frankfurt/Main, New York, Paris, Wien.

Bassnett, Susan.1991. Translation Studies, Rev. ed. London and New York: Routledge Co. Ltd.

The brochure, Verkommenes Ufer, Medeamaterial, Landschaft mit Argonauten, NSD, New Delhi, 2001.

Calandra, Devis, 1983. New German Theater, Macmillan Press Ltd., London and Basingstoke. 
Fernandes, Alinne Balduìno P. 2010. Between Words and Silences: Translating for the Stage and the Enlargement of Paradigms, Scientia Traductionis, n. 7.

https://periodicos.ufsc.br/index.php/scientia/article/viewFile/1980-

4237.2010n7p119/13470

Fischer - Lichte, Erika, 2004. Ästhetik des Performativen, Suhrkamp Verlag.

Fischer - Lichte, Erika: Die Inszenierung der Übersetzung als kulturelle Transformation, in: "Soziale und theatralische Konvention als Problem der Dramenübersetzung", (Fischer - Liche, Erika, Paul, Fritz, Schultze, Brigitte and Turk, Horst (ed.)), Gunter Narr Verlag, Tübingen. pp. 129- 144.

Ghani, Dr. Hana Khalief: The Translator as Dramatist: On the Problems of Translating Dramatic Text.

http://iasj.net/iasj?func=fulltext\&aId $=10783$

Jain, Nemichandra, 2003..ASIDES, National School of Drama, New Delhi.

Lotringer, Sylvere, ed.1990. Schütze/Bernhard \& Catherine (Übersetzer): HEINER MÜLLER. Germania. Semiotext (e), Foreign Agent Series.

Müller, Heiner, 1992. Krieg ohne Schlacht, Kiepenheuer \& Witsch.

Müller, Heiner, 2006. Verkommenes Ufer, Medeamaterial, Landschaft mit Argonauten, Henschel Schauspiel Theater Verlag, Berlin GmbH, 2006.

Pavis, Patrice. 1992. Theatre at the Crossroads of Culture (translated by Loren Kruger), Routledge, London and New York.

Peghinelli, Andrea: Theatre Translation as Collaboration: A Case in Point in British Contemporary Drama, in: "Journal for Communication and Culture 2", no. 1 (Spring 2012) : 20-30, (C Institute for Communication and Culture, E - ISSN \& ISSN - L : 2247 - 4404. www.jcc.icc.org.ro, contact@,cc.org.ro.

Neef, Sigfired.1989. Ruth Berghaus und Heiner Müller im Gespräch. In: "Sinn und Form", 41. Jahr, 1. Heft, S. 114-131. 
Thomas, Jerry, 2002. Doyen of Hindi Theatre, in “The Hindu”, Dec 19.

http://www.thehindu.com/thehindu/mp/2002/12/19/stories/2002121901060 $\underline{200 . h t m}$

\section{Translation of German and Hindi Texts / Quotes in English:}

1. "Einerseits kann die Dramenübersetzung - wie alle anderen Übersetzungen auch - als Träger der Vermittlung fungieren, wenn sie in der Lektüre rezipiert wird; andererseits aber läßt sie sich als Vorlage für eine Inszenierung verwenden, die dann ihrerseits als eigentlicher Träger der Vermittlung fungieren wird.” (German).

"On the one hand, the drama translation - like all the other translations also - acts as a career of the mediation, if they are received in the reading; but on the other hand they can be used as a template/draft for a performance that will in turn act as a real bearer of mediation." (Translation mine)

(Fischer - Lichte, Erika: Die Inszenierung der Übersetzung als kulturelle Transformation, in: Fischer - Liche, Erika, Paul, Fritz, Schultze, Brigitte and Turk, Horst (ed.): Soziale und theatralische Konvention als Problem der Dramenübersetzung, Gunter Narr Verlag, Tübingen. p. 129-144.)

2. German Text: Mueller, Heiner: Verkommenes Ufer Medeamaterial Landschaft mit Argonauten, Henschel Schauspiel Theaterverlag Berlin GmbH, 2006.

Hindi Text: The brochure, Verkommenes Ufer, Medeamaterial, Landschaft mit Argonauten, NSD, New Delhi, 2001.

English Text: Despoiled Shore Medea-material Landscape with Argonauts, By Heiner Mueller

Translation (C) Dennis Redmond 2002.

1. “Aufplatzt Ihre Weiber stellen das Essen warm" (German)

"sigri par paka rahi hai bhojan bhat" (Hindi)

"Their women serve the food warm" (English)

2. "Soll ich von mir reden Ich wer

Von wem ist die Rede wenn

Von mir die Rede geht Ich Wer ist das" (German)

"kiski baat hoti hai-

jab meri baat hoti hai - main kaun - aai

ye kaun hai?" (Hindi)

"Am I supposed to talk about myself I who

Of whom are we speaking if

The talk is of me I Who is that" (English)

3. "MEIN GROSSVATER WAR

IDIOT IN BÖOTIEN” (German) 
"mere lakkaddada boatia ke idiot" (Hindi)

"MY GRANDFATHER WAS

AN IDIOT IN BOATIA" (English)

4. "Gang durch die Vorstadt Ich Mein Tod" (German)

"Walk through the suburbs I My death" (English)

5. "SEEMANNSBRAUT IST DIE SEE" (German)

"Mallahan ki dulhin hai - sagar" (Hindi)

“THE SEA IS THE SAILOR'S BRIDE” (English)

6. "So stand Nero über Rom im Hochgefühl

Bis der Wagen vorfuhr Sand im Getriebe" (German)

"Nero. Aise hi Nero Rom ke upar

rama khada tha mahawinash mein

ki jab tak yaan aaye - nahin rang mein bhang. (lila mein vyaghat nahi)"

(Hindi)

"Thus stood Nero over Rome in euphoria

Until the wagon rolls up Sand in the gears (English)

7. "Ein Wolf stand auf der Straße als er auseinanderbrach" (German)

"Gadud dev sa ada raha sadak par jab tak sab dhwast hua nahi" (Hindi)

"A wolf stood on the street when it broke into pieces" (English)

3. "Die Inszenierung "übersetzt" daher das aus einer fremden Sprache in die eigene übersetzte Drama aus einer fremden (der Ausgangskultur) in die eigene Kultur, indem sie es auf der Bühne unter den Bedingungen produziert, welche ihre Kultur

(die Zielkultur) für theatralische Prozesse vorsieht. Diese Bedingungen realisieren sich als eine bestimmte Menge einerseits von theatralischen, andererseits von sozialen Konventionen, die in ihrer Gesamtheit den Rahmen darstellen, innerhalb dessen die Inszenierung der Übersetzung als Prozeß einer kulturellen Tranformation vollzogen wird." (German)

"The performance translates from a foreign language in its own translated drama, from foreign culture in its own culture, so that the performance produces the drama on the stage under the conditions, which the target culture forsees for the theatrical process. Theseconditions present the frames, which realize themselves out of theatrical as well associal conventions. Within this frame the performance of the

translated text works as cultural transformation.” (English) (translation mine)

(Fischer - Lichte, Erika: Die Inszenierung der Übersetzung als kulturelle Transformation, in: 
Fischer - Liche, Erika, Paul, Fritz, Schultze, Brigitte and Turk, Horst (ed.): Sozialeund theatralische Konvention als Problem der Dramenübersetzung, Gunter Narr Verlag, Tübingen. p. 129- 144.)

4. "This specialization does not interest me, this division of the work, rather the theater as a complete organism" (Translation mine)

"Mich interessierte natürlich nicht diese Spezialisierung, diese Arbeitsteilung, sondern das Theater als ganzer Organismus." (German)

(Müller, Heiner: Krieg ohne Schlacht, Kiepenheuer \& Witsch, 1992, S. 98.)

5. German Text: Mueller, Heiner: Verkommenes Ufer Medeamaterial Landschaft mit Argonauten, Henschel Schauspiel Theaterverlag Berlin GmbH, 2006.

Hindi Text: The brochure, Verkommenes Ufer, Medeamaterial, Landschaft mit Argonauten, NSD, New Delhi, 2001.

English Text: Despoiled Shore Medea-material Landscape with Argonauts, By Heiner Mueller

Translation (C) Dennis Redmond 2002.

1. "Yah vriksh nahi badhega mujhse upar" (Hindi) "DIESER BAUM WIRD MICH NICHT ÜBERWACHSEN Fischleichen" (German)

"THIS TREE SHALL NOT GROW OVER ME Fish-corpses" (English)

2. "Sambhog karo aaja pritam pyare" (Hindi) "STOSS MICH KOMM SÜSSER" (German) “SLAM IT TO ME COME SWEETIE” (English)

3. "Aur thal par - samudra tal parMedea - bahon me simta uska Nanha bhai -

Wo gahan visho ki gyata - vidushi" (Hindi)

"Auf dem Grund aber Medea den zerstückten

Bruder im Arm Die Kennerin

Der Gifte" (German)

"On the ground however Medea the hacked-apart

Brother in her arms She who is skilled

In poisons" (English) 